\title{
Screening of milk samples for sub-clinical and clinical mastitis by using
} CMT and SCC

\author{
Authors \\ R. Lakshmi ${ }^{1}$, K.K. Jayavardhanan ${ }^{2}$ \\ ${ }^{1} \mathrm{PhD}$ Scholar, Department of Veterinary Biochemistry, College of Veterinary and Animal Sciences, \\ Thrisuur, Kerala, India \\ Email:lakshmivetbio@gmail.com \\ ${ }^{2}$ Professor \& Head, Department of Veterinary Biochemistry, College of Veterinary and Animal Sciences, \\ Thrisuur, Kerala, India \\ Email: jayavardhanan@kvasu.ac.in
}

\begin{abstract}
The present study was conducted to screen the sub-clinical and clinical mastisis samples collected from Kerala veterinary University Livestock Farm, Mannuthy, by using California mastitis Test and Somatic cell count. A total of 80 lactating crossbred cows were subjected to following screening test for detecting subclinical mastitis (SCM) and clinical mastitis. Screening results revealed 28 cows were positive for subclinical mastitis (35 per cent), 19 cows were positive for clinical mastitis (23.75 per cent) and 33 cows were found to healthy (41.25 per cent). These three groups of samples were subjected for somatic cell count. A significant $(P<0.01)$ increase in milk somatic cell count SCC in subclinical and clinical mastitis affected cows were noticed when compared with healthy crossbred cows. SCC is was found to be the most accurate method for detecting subclinical mastitis.
\end{abstract}

Key Word: Mastisis, California mastitis Test and Somatic cell count.

\section{Introduction}

Mastitis is defined as inflammation of the mammary tissue parenchyma, characterized by physical, chemical and usually bacteriological changes in milk and pathological changes in glandular tissue. Mastitis, in particular sub-clinical mastitis, is one of the most prevalent diseases of high yielding dairy animals (Dhumka and Srivastava, 2003; Sharma and Prasad, 2003). It is of great economic importance to the dairy industry (Saluja et al., 2005), resulting in reduction in milk yield and quality (Oliveira et al., 2000). Mastitis is only second to foot and mouth disease as the most challenging disease in dairy animals (Sharma et al., 2007).
There are two forms of mastitis prevalent in terms of level of severity; clinical, and subclinical. Clinical form of mastitis shows visible symptoms whereas subclinical form does not show any visible symptoms. Clinical mastitis is threatening to a farmer in a dairy herd and treatment is given immediately to control it. But subclinical mastitis, which cannot be identified without a laboratory or field test, mostly remains unnoticed by the farmer. In India incidence of subclinical form mastitis was found to be more (varying from $10-50 \%$ in cows and $5-20 \%$ in buffaloes) when compared to clinical mastitis $(1-10 \%)$.

The presence of clinical mastitis is quite easy to asses, whereas the diagnosis of the subclinical form 
can be more difficult and requires laboratory assays. Various research works have been done to find out an effective way for the early detection of mastitis. At present, the most commonly used 'cow side' test, the California Mastitis Test (CMT) based on somatic cell count (SCC) along with bacterial culture is considered as the gold standard method. Currently, methods such as measurement of $\mathrm{N}$ acetyl-b-D-glucosaminidase (NAG-ase), lactate dehydrogenase (LDH), electrical conductivity (EC), and molecular methods such as polymerase chain reaction (PCR) technology are used less frequently. In this context we focused on CMT and SCC method for screening milk samples affected with mastitis.

\section{Materials and Methods}

\section{Screening for experimental animals}

University livestock farm, Mannuthy formed the venue for selecting experimental animals. A total of 80 lactating crossbred cows were subjected to following screening test for detecting sub-clinical mastitis (SCM) and clinical mastitis.

\section{California Mastitis Test (CMT)}

The California Mastitis Test (CMT) was performed as per Mellenberger (2001) to predict the somatic cell count of milk. When milk and CMT reagent are mixed in equal amounts, the CMT reagent dissolves or disrupts the outer cell wall and the nuclear cell wall of any leucocyte, which are primarily fat (detergent dissolves fat). DNA is now released from the nuclei. DNA will string or gel together to form a stringy mass. As the number of leucocytes increase in a quarter, the amount of gel formation will increase in a linear fashion. Therefore, the gel formation can be "scored or read" as in Table 1 . Collection timings and procedure were kept uniform in order to avoid the variation between experimental units due to sample collection, as the somatic cell count varies based on several factors such as frequency of milking, interval between milking.

\section{Somatic Cell Count (SCC)}

Milk (10 $\mathrm{l})$ was taken and spread in a $1 \mathrm{sq} \mathrm{cm}$ area in a clean microscopic slide and stained with
Modified Newman's stain, the SCC was made using a compound microscope (Packard et al., 1992). Based on screening results, the population were separated into apparently healthy crossbred cows, SCM affected crossbred cows and clinical mastitis affected crossbred cows.

Table 1. CMT score and somatic cell count (SCC)

\begin{tabular}{|l|l|l|}
\hline $\begin{array}{l}\text { CMT } \\
\text { Score }\end{array}$ & $\begin{array}{l}\text { Somatic count } \\
\text { (Cells per millilitre) }\end{array}$ & Description of reaction \\
\hline $\begin{array}{l}\mathrm{N} \\
\text { (negative) }\end{array}$ & 100,000 & $\begin{array}{l}\text { No thickening, } \\
\text { homogeneous }\end{array}$ \\
\hline $\mathrm{T}$ (trace) & 300,000 & $\begin{array}{l}\text { Slight thickening. } \\
\text { Reaction disappears in 10 } \\
\text { seconds }\end{array}$ \\
\hline 1 & 900,000 & $\begin{array}{l}\text { Distinct thickening, no } \\
\text { gel formation }\end{array}$ \\
\hline 2 & $2,700,000$ & $\begin{array}{l}\text { Thickens immediately, } \\
\text { begins to gel, levels in the } \\
\text { bottom of cup }\end{array}$ \\
\hline 3 & $8,100,000$ & $\begin{array}{l}\text { Gel is formed, surface } \\
\text { elevates, with a central } \\
\text { peak above the mass }\end{array}$ \\
\hline
\end{tabular}

\section{Results and Discussion}

Mastitis is the inflammatory process where the accumulations of somatic cells are very well established. Currently the diagnosis of mastitis is mostly based on the somatic cell count. A total of 80 crossbred lactating cows were screened for subclinical and clinical mastitis using CMT. Screening results revealed 28 cows were positive for subclinical mastitis (35 per cent), 19 cows were positive for clinical mastitis (23.75 per cent) and 33 cows were found to healthy (41.25 per cent). These three groups of samples were subjected for somatic cell count.

Somatic Cell Count (SCC) in sub-clinical, clinical and healthy samples was done by direct microscopic method. Group wise differences were studied using one way ANOVA. Significant $(\mathrm{P}<0.01)$ increase in milk SCC in mastitis affected cows were noticed when compared with healthy crossbred cows (Table 2).

Table 2. SCC in healthy, sub-clinical and clinical groups of samples (Mean $\pm \mathrm{SE}$ )

\begin{tabular}{|l|l|l|ll|}
\hline Parameter & Healthy & $\begin{array}{l}\text { Sub- } \\
\text { clinical }\end{array}$ & Clinical & \\
\hline $\begin{array}{l}\text { SCC } \\
\left(\text { in } \times 10^{5} \text { cells } / \mathrm{ml}\right)\end{array}$ & $\begin{array}{l}0.54 \\
0.08^{\mathrm{a}}\end{array}$ & \pm & $\begin{array}{l}25.77 \\
4.62^{\mathrm{b} * *}\end{array}$ & $\begin{array}{l}82.43 \\
0.91^{\mathrm{c} * *}\end{array}$ \\
\hline
\end{tabular}


The somatic cell count plays an important role in protecting the mammary gland against infectious diseases. When infection starts, a large number of neutrophils are migrated from the blood stream via diapedesis into the milk and account for more than $90 \%$ of the SCC (Sordillo et al., 1997). The rate at which neutrophils are activated and migrated to the site of infection determines the severity of the infection. Weak recruitment of neutrophils at the site of infection was also believed to result in a higher susceptibility of mastitis (Shuster et al., 1996). It has been described that cows with a higher SCC are less susceptible to infections in comparison with cows with low SCC (Schukken et al., 1994 and Peeler et al., 2000). Our results shows that, the somatic cell count was increased in both subclinical and clinical case of mastitis when compared to healthy animal, similar to the reports of Miller et al. (1999).

\section{Conclusion}

SCC as a screening test for the diagnosis of subclinical mastitis and clinical mastitis was accurate. CMT also has been proved as a good screening test to be used during milking in all the animals with suspect mastitis.

\section{Reference}

1. Dhumka, V.K and Srivastava, A.K. 2003. Pharmacology of antibiotics used in the treatment of mastitis: An overview. Proceedings on $4^{\text {th }}$ round table on mastits, IVRI, Izatnagar. 97-111

2. Mellenberger, R. 2001. California Mastitis Test (CMT): An Invaluable Tool forManaging Mastitis, Dept. of Animal Sciences, Michigan State University. 2001:1.

3. Miller, K., Brezinska-Slebodzinska, E., Madsen F. C. 1993. Oxidative stress, antioxidants and animal function. J. Dairy Sci. 76: 2812-2823.

4. Oliveira, A.P., Watts, J.L., Salmon, S.A and Aarestrup, F.M. 2000. Antimicrobial susceptibility of S.aureus isolated from bovine mastitis and the United States, $J$. Dairy Sci., 83: 855-862.

5. Packard, V.S., Tatini, S., Fugua, R., Heady, J and Gilman, C. 1992. Direct microscopic methods for bacteria or somatic cells, In Methods for the Examination of Dairy Products, 309-321

6. Peeler, E. J., Green, M. J., Fitzpatrick, J. L., Morgan, K.L., Green, L.E. 2000. Risk factors associated with clinical mastitis in low somatic cell count British dairy herds. $J$. Dairy Sci., 83: 2464-2472.

7. Saluja, P.S., Gupta, S.L., Kapur and Sharma, A. 2005. Antibiogram of bacterial isolates of bovine intramammary origin. Indian vet. J., 82: 323-324.

8. Schukken, Y.H., Mallard, B.A., Dekkers, J.C., Leslie, K.E, Stear, M.J. 1994. Genetic impact on the risk of intramammary infection following Staphylococcus aureus challenge. J. Dairy Sci., 77: 639-647.

9. Sharma, A and Prasad, B. 2003. Prevalence and therapy of mastitis in dairy animals of Kangra valley of Himachal Pradesh., Proceedings on $4^{\text {th }}$ round table on mastitis .

10. Sharma, N., Maiti, S.K and Sharma, K.K. 2007. Prevalence, Etiology and Antibiogram of Micro-organism associated with subclinical mastitis in buffaloes in Durg, Chhattisgarh state (India). Int. J. Dairy Sci., 1: 7-12.

11. Shuster, D.E., Lee, E.K and Kehrli, M.E. 1996. Bacterial growth, inflammatory cytokine production, and neutrophil recruitment during coliform mastitis in cows within ten days after calving, compared with cows at midlactation. Am. J. Vet. Res., 57: 1569-1575.

12. Sordillo, L.M., Shafer-Weaver, K. and DeRosa, D. 1997. Immunobiology of the mammary gland. Journal of Dairy Science, 80: 1851-1865. 